\title{
Inoculation of containerized Pinus halepensis (Miller) seedlings with basidiospores of Pisolithus arhizus (Pers) Rauschert, Rhizopogon roseolus (Corda) Th M Fr and Suillus collinitus (Fr) O Kuntze
}

\author{
P Torres, M Honrubia \\ Departamento de Biologia Vegetal (Botánica), Facultad de Biología, \\ Universidad de Murcia, Campus de Espinardo, 30100 Murcia, Spain
}

(Received 5 April 1993; accepted 31 March 1994)

\begin{abstract}
Summary - Pinus halepensis Miller seedlings grown in containers were inoculated with 3 different basidiospore concentrations of Pisolithus arhizus (Pers) Rauschert, Rhizopogon roseolus (Corda) Th $\mathrm{M} \mathrm{Fr}$ and Suillus collinitus ( $\mathrm{Fr}$ ) O Kuntze, in sterile and unsterilized substrate. Six months after germination, the seedlings were evaluated for ectomycorrhizal development and fungal species were isolated from any ectomycorrhizas synthesized. Height, dry weight and percentages of ectomycorrhizas were recorded. There were no significant differences between the 3 inoculated fungal species used on the seedling growth. The highest mean values of height, $d r y$ weight and percentage of ectomycorrhizas were obtained with seedlings inoculated with Pisolithus arhizus in sterile substrate.
\end{abstract}

inoculation / basidiospore / ectomycorrhizas / Pinus halepensis / Pisolithus arhizus / Rhizopogon roseolus / Suillus collinitus

Résumé - Inoculation de plantules de Pinus halepensis Miller, cultivées en contenants, dans des substrats stériles et non stériles, avec 3 concentrations sporales de Pisolithus arhizus (Pers) Rauschert, Rhizopogon roseolus (Corda) Th M Fr et Suillus collinitus (Fr) O Kuntze. Six mois après la germination, les espèces fongiques ont été isolées à partir des ectomycorhizes synthétisées. La hauteur, le poids secs et les pourcentages d'ectomycorhizes ont été déterminés. On n'a pas mis en évidence de différences significatives entre les 3 espèces fongiques étudiées sur la croissance des plantules. Cependant, les meilleurs résultats en termes de croissance et d'infection mycorhizienne ont été obtenus sur substrat stérile avec Pisolithus arhizus.

inoculation / basidiospore / ectomycorhizes / Pinus halepensis / Pisolithus arhizus / Rhizopogon roseolus / Suillus collinitus 


\section{INTRODUCTION}

The controlled mycorrhizal infection of seedlings intended for use in afforestation schemes is not a common practice in Spanish nurseries. Although the use of soils from established plantations does ensure a degree of infection by ectomycorrhizal fungi, the seedlings tend to be colonized by fungi adapted to nursery conditions and these probably disappear once they are planted out. Furthermore, the use of natural soil as an inoculum exposes the nursery to possible infection by pest or pathogens (Molina, 1977).

The use of ectomycorrhizal fungus spores is the simplest and most economic method for the inoculation of large numbers of seedlings since they can be incorporated in the water used for irrigation. However, it is first necessary to ascertain whether the spores are viable and capable of germinating in the rizosphere of the seedlings to be inoculated (Miller et al, 1993; Torres and Honrubia, 1994a).

During the last 20 years, many successful experiments have been carried out to inoculate seedlings with basidiospores of specific fungal species and many authors have used these propagules for the formation of ectomycorrhizas in different species of pine (Marx and Ross, 1970; Theodorou, 1971, 1984; Theodorou and Bowen, 1973; Marx, 1976; Hodson, 1979; Marx et al, 1979; Ruehle, 1980; Alvarez and Trappe, 1983; Beckjord et al, 1984; Marx and Bell, 1985; Marx et al, 1989).

In the present study, 3 fungal species were chosen for the basidiospore inoculation of Pinus halepensis Miller (Aleppo pine) seedlings: Pisolithus arhizus (Pers) Rauschert, Rhizopogon roseolus (Corda) Th M Fr and Suillus collinitus ( $\mathrm{Fr}$ ) O Kuntze, all of which grow naturally in Aleppo pine forests of SE Spain and are therefore well adapted to the semiarid conditions of this zone.

$P$ arhizus, which forms large fruit bodies containing many basidiospores, is an excellent example of an ectomycorrhizal species adapted to adverse conditions and has a wide range of host plants (Marx, 1977). The other 2 species used are very common in $P$ halepensis forests, and their fruit bodies are found in large quantities under these trees. These species form ectomycorrhizas in vitro with $P$ halepensis (Torres et al, 1991; Torres and Honrubia, 1994b) and have a high percentage of viable and active basidiospores in slurries obtained from fruit bodies (Torres and Honrubia, 1994a).

The present study had 3 objectives. First, to examine whether the inoculation of soil with basidiospores of $P$ arhizus, $R$ roseolus and $S$ collinitus is effective for the development of ectomycorrhizas. Secondly, to isolate the fungal species from the ectomycorrhizas obtained after inoculation to see whether the synthesis established corresponded to the fungus. Thirdly, to determine the effect of different spore concentrations on seedling development in sterile and unsterilized substrates.

\section{MATERIALS AND METHODS}

Sherwood-type Trioum root-trainers containers (175 $\mathrm{ml}$ capacity) were used after being sterilized in water and bleach (1:1). The containers were filled with 2 types of substrate: 1) sterile peat, soil and vermiculite $(1: 1: 1 \mathrm{v} / \mathrm{v} / \mathrm{v})$; or 2$)$ unsterilized peat, soil and vermiculite $(1: 1: 1 \mathrm{v} / \mathrm{v} / \mathrm{v})$. The soil used in both cases came from a local reforested pine forest of approximately 20 years standing. Substrate 1 was steam-sterilized 3 times at $100^{\circ} \mathrm{C}$ for $1 \mathrm{~h}$ (once a week for 3 weeks). The substrate $\mathrm{pH}$ in both cases was approximately 6.5 (in water).

The $P$ halepensis seeds came from the $E$ Valle nursery belonging to the Servicio de Montes de la Agencia Regional para el Medio Ambiente y la Naturaleza de la Región de Murcia. They 
underwent no prior scarification or stratification treatment before germination.

The seeds were rinsed in tapwater and then surface sterilized with $30 \% \mathrm{H}_{2} \mathrm{O}_{2}$ for $20 \mathrm{~min}$. After sterilization they were sown in the containers (approximately 5 seeds/cavity). Germination took place at $10-15 \mathrm{~d}$ and then all cavities were thinned to 1 seedling.

Fruit bodies of $P$ arhizus came from $P$ halepensis plantations in EI Valle (Murcia). The basidiospores were suspended in sterile distilled water with Tween 80.

The inocula of $R$ roseolus and $S$ collinitus were prepared according to the method described by Castellano and Molina (1989), from fruit bodies collected in Aleppo pine plantations in EI Valle (Murcia). This method consists of preparing spore slurries from fragments of hymenium, which are then triturated in sterile distilled water. Spore concentration in the final solution was calculated with a hemacytometer.

The slurries were stored for $10-15 \mathrm{~d}$ at $3-4^{\circ} \mathrm{C}$ before use. Spore viability and activity has been shown to decrease considerably after $30 \mathrm{~d}$ of cold storage (Torres and Honrubia, 1994a).

\section{Experimental design}

Three spore suspensions of different concentrations were prepared for each fungal species: $10^{6}$, $4 \times 10^{6}$ and $10^{7}$ basidiospores $/ \mathrm{ml}$. For each ectomycorrhizal fungus one container with sterile and another with unsterilized substrate for each spore concentration were prepared ( 6 treatments).

Four inoculation batches were made at $15 \mathrm{~d}$ intervals following seed germination. The final quantity of basidiospores per seedling was $4 x$ $10^{6}, 1.6 \times 10^{6}$ and $4 \times 10^{7}$ in each treatment.

Control seedlings in each substrate received no inoculation. The experiment started in December and finished in May, using greenhouse conditions with a natural temperature and light cycle. The plants were watered once or twice a day as necessary.

Six months after germination, 15 seedlings were randomly selected from each of the 6 treatments and from the control groups. The height and dry weight of top and root were recorded. The percentage of ectomycorrhizas was calculated by counting the infected and uninfected tips. Tips were considered as mycorrhizal when man- the was clearly observed. If mantle was not clear or not present mycorrhizal colonization was determined making cross-sections and examining microscopically for the presence of a Hartig net. Tips appearing without mantle and/or Hartig net were not counted. For the dry weight measurements, the seedlings were dried at $65^{\circ} \mathrm{C}$ for $16 \mathrm{~h}$.

All data were subjected to analysis of variance and significant differences was carried out between the means using a Duncan's test ( $P \leq$ 0.05) (Duncan, 1955).

\section{Isolation of fungal symbionts from ectomycorrhizas}

In order to check which fungi are present in the root systems, ectomycorrhizas were isolated. These mycorrhizas had previously been characterized morphologically (ramification, colour, mantle surface, mycelial strands, etc) using our previous knowledge of synthesized in vitro examples as a basis (Torres et al, 1991; Torres and Honrubia, 1994b). Mycorrhizal roots were taken from 15 randomly selected plants. These were surface sterilized and placed in petri dishes with MMN medium (Marx, 1969).

Sterilization was carried out as follows. The mycorrhizal roots were vigorously washed in a solution of $0.01 \%$ Tween 80 to eliminate soil particles. They were washed in sterile distilled water for $30 \mathrm{~min}$ and then surface sterilized with $30 \%$ $\mathrm{H}_{2} \mathrm{O}_{2}$ for $30-40 \mathrm{~s}$. Finally, they were once again washed in sterile distilled water.

After isolation, the mycelia were compared with those of the fungal species used as inoculum obtained from fruit body tissues. In addition to macroscopic characterization of the mycelia, their microscopic characteristics were examined (clamp connections, ramification, size, pigmentation, etc).

\section{RESULTS}

Tables $1-\mathrm{V} \mid$ show the mean values for the height, dry weight and percentage of ectomycorrhizas of the 15 randomly selected seedlings from each group. These are followed by a letter according to the result of Duncan's test. 
Table I. Growth and ectomycorrhizal development of 6-month-old $P$ halepensis seedlings in sterile substrate inoculated with $P$ tinctorius basidiospores.

\begin{tabular}{|c|c|c|c|c|c|}
\hline \multirow{2}{*}{$\begin{array}{l}\text { Treatment } \\
\text { (spores/pine) }\end{array}$} & \multirow{2}{*}{$\begin{array}{l}\text { Height } \\
(\mathrm{cm})\end{array}$} & \multicolumn{2}{|c|}{ Dry weight (mg) } & \multicolumn{2}{|c|}{ Ectomycorrhiza (\%) } \\
\hline & & Top & Root & $\mathrm{P}$ tinctorius & Other \\
\hline $4 \times 10^{6}$ & $12.18^{b}$ & $236 b$ & $206^{d}$ & $55.4 \mathrm{c}$ & $0^{a}$ \\
\hline $1.6 \times 10^{7}$ & $12.00^{b}$ & $223^{b}$ & $183^{c}$ & $51.2^{c}$ & $\mathrm{O}^{\mathrm{a}}$ \\
\hline $4 \times 10^{7}$ & $11.00^{b}$ & $212^{b}$ & $159 b$ & $42.6^{b}$ & $0 a$ \\
\hline 0 & 7.67 a & $130^{a}$ & $120^{a}$ & $0^{a}$ & $0^{a}$ \\
\hline
\end{tabular}

Means in a column sharing a common letter do not differ significantly using Duncan's test at $P \leqslant 0.05$.

Table II. Growth and ectomycorrhizal development of 6-month-old $P$ halepensis seedlings in unsterilized substrate inoculated with $P$ tinctorius basidiospores.

\begin{tabular}{llcccc}
\hline $\begin{array}{l}\text { Treatment } \\
\text { (spores/pine) }\end{array}$ & $\begin{array}{l}\text { Height } \\
(\mathrm{cm})\end{array}$ & \multicolumn{2}{c}{ Dryweight $(\mathrm{mg})$} & \multicolumn{2}{c}{ Ectomycorrhiza (\%) } \\
\cline { 3 - 5 } & & Top & Root & P tinctorius & Other \\
\hline & & & & & \\
\hline$\times 10^{6}$ & $6.56^{\mathrm{a}}$ & $116^{\mathrm{a}}$ & $74 \mathrm{a}$ & $6 \mathrm{~b}^{\mathrm{b}}$ & $41.3 \mathrm{a}$ \\
$1.6 \times 10^{7}$ & $9.25^{\mathrm{b}}$ & $159^{\mathrm{b}}$ & $107^{\mathrm{b}}$ & $14.8^{\mathrm{c}}$ & $38.2 \mathrm{a}$ \\
$4 \times 10^{7}$ & $9.40^{\mathrm{b}}$ & $176^{\mathrm{b}}$ & $139 \mathrm{c}$ & $16.3 \mathrm{c}$ & $40.7 \mathrm{a}$ \\
0 & $7.85^{\mathrm{a}}$ & $103^{\mathrm{a}}$ & $69 \mathrm{a}$ & $0 \mathrm{a}$ & $36.5^{\mathrm{a}}$
\end{tabular}

Means in a column sharing a common letter do not differ significantly using Duncan's test at $P \leq 0.05$.

Table III. Growth and ectomycorrhizal development of 6-month-old $P$ halepensis seedlings in sterile substrate inoculated with $R$ roseolus basidiospores.

\begin{tabular}{|c|c|c|c|c|c|}
\hline \multirow{2}{*}{$\begin{array}{l}\text { Treatment } \\
\text { (spores/pine) }\end{array}$} & \multirow{2}{*}{$\begin{array}{l}\text { Height } \\
(\mathrm{cm})\end{array}$} & \multicolumn{2}{|c|}{ Dry weight (mg) } & \multicolumn{2}{|c|}{ Ectomycorrhiza (\%) } \\
\hline & & Top & Root & $\mathrm{R}$ roseolus & Other \\
\hline $4 \times 10^{6}$ & $12.44^{c}$ & $235^{c}$ & $168^{c}$ & $39.5^{b}$ & $0^{a}$ \\
\hline $1.6 \times 10^{7}$ & $10.94 b$ & $209 b$ & $143 b c$ & $43.2^{b}$ & $0^{a}$ \\
\hline $4 \times 10^{7}$ & $10.59 b$ & $195^{b}$ & $129^{b}$ & $38.5^{b}$ & $\mathrm{O}^{\mathrm{a}}$ \\
\hline 0 & 7.67 a & $130 a$ & $120^{a}$ & $0^{a}$ & $0^{a}$ \\
\hline
\end{tabular}

Means in a column sharing a common letter do not differ significantly using Duncan's test at $P \leq 0.05$ 
Table IV. Growth and ectomycorrhizal development of 6-month-old $P$ halepensis seedlings in unsterilized substrate inoculated with $R$ roseolus basidiospores.

\begin{tabular}{|c|c|c|c|c|c|}
\hline \multirow{2}{*}{$\begin{array}{l}\text { Treatment } \\
\text { (spores/pine) }\end{array}$} & \multirow{2}{*}{$\begin{array}{l}\text { Height } \\
(\mathrm{cm})\end{array}$} & \multicolumn{2}{|c|}{ Dry weight (mg) } & \multicolumn{2}{|c|}{ Ectomycorrhiza (\%) } \\
\hline & & Top & Root & $R$ roseolus & Other \\
\hline $4 \times 10^{6}$ & $9.19 \mathrm{~b}$ & $135^{b}$ & $82^{b}$ & $25.3^{b}$ & $27.8^{a}$ \\
\hline $1.6 \times 10^{7}$ & $9.25^{b}$ & $158 \mathrm{bc}$ & $110^{c} \mathrm{c}$ & $28.2^{b}$ & $31.3 \mathrm{a}$ \\
\hline $4 \times 10^{7}$ & $9.44^{b}$ & $171^{c}$ & $118^{c}$ & $35.4^{c}$ & $26.7^{a}$ \\
\hline 0 & $7.85^{a}$ & $103 a$ & $69 a$ & $0^{a}$ & $36.5^{a}$ \\
\hline
\end{tabular}

Means in a column sharing a common letter do not differ significantly using Duncan's test at $P \leq 0.05$.

Table V. Growth and ectomycorrhizal development of 6-month-old $P$ halepensis seedlings in sterile substrate inoculated with $S$ collinitus basidiospores.

\begin{tabular}{|c|c|c|c|c|c|}
\hline \multirow{2}{*}{$\begin{array}{l}\text { Treatment } \\
\text { (spores/pine) }\end{array}$} & \multirow{2}{*}{$\begin{array}{l}\text { Height } \\
(\mathrm{cm})\end{array}$} & \multicolumn{2}{|c|}{ Dry weight (mg) } & \multicolumn{2}{|c|}{ Ectomycorrhiza (\%) } \\
\hline & & Top & Root & $\mathrm{S}$ collinitus & Other \\
\hline $4 \times 10^{6}$ & $11.80 \mathrm{c}$ & $181^{c}$ & $173 c$ & $28.9^{b}$ & $0^{a}$ \\
\hline $1.6 \times 10^{7}$ & $10.35^{b}$ & $172^{b}$ & $141^{b}$ & $42.6^{c}$ & $0 a$ \\
\hline $4 \times 10^{7}$ & $9.54^{b}$ & $167^{b}$ & $135 \mathrm{~b}$ & $31.2^{b}$ & $0^{a}$ \\
\hline 0 & $7.67 \mathrm{a}$ & $130^{a}$ & $120^{a}$ & $0^{a}$ & $0^{a}$ \\
\hline
\end{tabular}

Means in a column sharing a common letter do not differ significantly using Duncan's test at $P \leq 0.05$.

Table VI. Growth and ectomycorrhizal development of 6-month-old $P$ halepensis seedlings in unsterilized substrate inocutated with $S$ collinitus basidiospores.

\begin{tabular}{lccccc}
\hline $\begin{array}{l}\text { Treatment } \\
\text { (spores/pine) }\end{array}$ & $\begin{array}{l}\text { Height } \\
(\mathrm{cm})\end{array}$ & \multicolumn{1}{c}{ Dry weight $(\mathrm{mg})$} & & \multicolumn{1}{c}{ Ectomycorrhiza (\%) } \\
& & Top & Root & S collinitus & Other \\
& $6.9 \mathrm{a}$ & $74^{\mathrm{a}}$ & $71^{\mathrm{a}}$ & $19.7^{\mathrm{c}}$ & $23.2 \mathrm{a}$ \\
$4 \times 10^{6}$ & $8.04^{\mathrm{a}}$ & $91^{\mathrm{a}}$ & $73^{\mathrm{a}}$ & $20.3^{\mathrm{c}}$ & $27.0^{\mathrm{b}}$ \\
$1.6 \times 10^{7}$ & $11.21^{\mathrm{b}}$ & $105^{\mathrm{b}}$ & $74^{\mathrm{a}}$ & $8.5^{\mathrm{b}}$ & $35.5^{\mathrm{c}}$ \\
$4 \times 10^{7}$ & $7.85^{\mathrm{a}}$ & $103^{\mathrm{a}}$ & $69^{\mathrm{a}}$ & $0 \mathrm{a}$ & $36.5^{\mathrm{c}}$
\end{tabular}


From tables I and II, which correspond to the seedlings inoculated with $P$ arhizus, it can be seen that there are no significant differences between height and dry weight of seedlings inoculated with the 3 spore concentrations in sterile substrate, although the difference is highly significant between these seedlings and the uninoculated control ones. The percentage of $P$ arhizus mycorrhizal colonization is higher with lower spore concentrations. It is therefore possible that a threshold level of spore concentration exists, beyond which any increase in the number of propagules has a negative effect on mycorrhizal percentage and total root dry weight. As suggested by Marx (1976) self-inhibition may exist at high spore concentrations.

In the unsterilized substrate, however, there are clear differences between the smallest spore concentration and the other 2 used; the first always provides lower height and dry weight data. Root ectomycorrhizal colonization is far below that found in the sterilized soil and the appearance of ectomycorrhizas of native symbionts exercises a competitive effect on the inoculated fungus.

As a rule, the control seedlings showed the lowest height and dry weight values even in the unsterilized soil, where an unidentified species developed ectomycorrhizas, which we will refer to as Suillus-type. In the seedlings in sterile substrate and inoculated with $R$ roseolus (tables III and IV), significant differences were observed for height and dry weight between the smallest spore concentration and the other 2 concentrations used. These data are highest in the lowest concentration and practically equal to the 2 higher concentrations. As in the previous case, there could well be a threshold level above which an increase in spore numbers might have a negative effect on plant growth. The percentages of $R$ roseolus ectomycorrhizas showed no difference between the 3 concentrations. This hypothetical negative effect produced by height concentration is not reflected in the actual proportion of mycorrhizas developed.

The values obtained for control seedlings in sterile substrate differ from those of the 3 spore inoculum concentrations used and no ectomycorrhizas were found in the root systems.

In unsterilized soil, there were no significant differences in height between the concentrations of basidiospores used. As regards dry weight, however, the first treatment (lowest spore concentration) differs from the other 2 , these values being higher than with greater spore concentrations. The percentages of $R$ roseolus ectomycorrhizas are far below those obtained in sterile soil, the highest values occurring with the highest concentration of basidiospores. There are also a high number of ectomycorrhizas developed by native symbionts, at a similar level to that formed by the inoculated fungus. It seems that, unlike the case of $P$ arhizus, there is no competition between the introduced fungus and those already present in the soil used.

The control plants in unsterilized substrate showed lower height and dry weight values than those which had been inoculated, although they form ectomycorrhizas with the previously described fungal species which appeared in the unsterilized soil.

The seedlings inoculated with $S$ collinitus (tables V and VI) in sterile substrate show significant differences between the data obtained with the lowest spore concentration and the 2 highest; all the values are much higher in the first and similar in the other 2. The appearance of a possible negative effect at high spore concentrations, as occurred with the other 2 species, is also observed, although the $S$ collinitus ectomycorrhizas percentages do not support this hypothesis. The highest percentage of ectomycorrhizas is found with the intermediate spore concentration; the other 2 concentrations are similar with no significant differences between them. 
The control seedlings showed no ectomycorrhizal infection and mean heights and dry weights were below those of the inoculated plants.

Significant differences were observed in the unsterilized soil between the height and top dry weight of seedlings inoculated with the highest spore concentration as opposed to the other 2 treatments; the values with the higher spore concentration had significantly higher dry weights. However, there was no difference in the 3 treatments as regards the mean dry weight of the roots. The percentages of ectomycorrhizas formed by $S$ collinitus were below those obtained in sterile substrate. The widescale presence of light-brown ectomycorrhizas of an unknown symbiont was noted. These were isolated and identified as a possible Suillus species.

Although the control seedlings showed ectomycorrhizal infection, they had lower height and dry weight values than the inoculated plants.

\section{CONCLUSIONS}

All the seedlings inoculated with $P$ arhizus, $R$ roseolus and $S$ collinitus developed ectomycorrhizas of identical characteristics to those described by Torres et al (1991) and Torres and Honrubia (1994b). The uninoculated seedlings grown in sterile substrates showed no ectomycorrhizal infection, while those grown in unsterilized substrates formed ectomycorrhizas with unknown symbionts. These mycorrhizas were morphologically similar to those formed by the genus Suillus, which was to be expected since the soil used came from forests where species of this genus predominated. These Suillus-type ectomycorrhizas were also observed in the inoculated seedlings grown in unsterilized substrates along with those formed by the inoculated fungus.
The corresponding mycelia were obtained from the mycorrhizas synthesized in vivo, which were identical to those synthesized in vitro for each of the inoculated fungi. The ectomycorrhizas were isolated in MMN medium and the mycelia which developed were compared with those in our collections obtained from the fruit bodies of the corresponding species. The macroscopic characteristics of the colonies and the microscopic characteristics of the hyphae were identical in all cases. This confirms innumerable previous studies showing that the use of basidiospores as inoculum is effective for carrying out controlled inoculation, especially if the substrate is sterilized beforehand. When an unsterilized substrate is used, the results in all cases suggest that the degree of ectomycorrhizal colonization is higher than in control experiments, although the percentage of ectomycorrhizas developed by native symbionts also rises.

In general terms, there are no large differences between the 3 fungal species used. The highest mean values of height, dry weight and percentage of ectomycorrhizas, was obtained in plants inoculated with $P$ arhizus. This agrees with the results of Ruehle et al (1981), who found that $P$ halepensis seedlings inoculated with $P$ arhizus mycelia showed higher values for height, fresh weight and root collar diameter than those inoculated with Thelephora terrestris or an uninoculated control. The latter fungus is very infective in sterile substrate but can be displaced by native species when unsterilized substrate is used. Ruehle (1980) mentioned somewhat similar results obtained with $P$ tadea inoculated with $P$ arhizus. The lowest levels of ectomycorrhizas developed by $P$ arhizus in this study occurred when they were colonized by $T$ terrestris, which is a very common species in nursery beds.

The use of sterilized substràte delays recolonization by competitors and antagonists of the fungal species used. The most noteworthy results are those which refer to 
the dry weight of the roots, which was much higher in sterilized than in unsterilized substrate. This points to an increase in the development of the root system, a very important characteristic when dealing with seedlings which are to be used in revegetation programmes in arid and semiarid areas. In conclusion, the importance of carefully controlled inoculation in the greenhouse and forest nurseries and the use of sterile substrates for growth containers, in these programmes is confirmed by the results obtained in this experiment.

\section{ACKNOWLEDGMENTS}

This research was supported by Icona-Lucdeme (Ministerio de Agricultura) and a grant from the Spanish Ministerio de Educación y Ciencia.

\section{REFERENCES}

Alvarez IF, Trappe JM (1983) Effects application rate and cold soaking pretreatment of Pisolithus tinctorius spores on effectiviness as nursery inoculum on western conifers. Can J For Res 13,533-537

Beckjord PR, Mcintosh MS, Hacskaylo E, Melhuish JH Jr (1984) inoculation of loblolly pine seedlings at planting with basidiospores of ectomycorrhizal fungi in chip form. Northeast For Exp Sta Res Note NE-324, $4 p$

Castellano MA, Molina R (1989) Mycorrhizae. In: The Container Tree Nursery (TD Landis et al, eds). Agric Handbook 674, Washington DC, USDA, Forest Service, $102-107$

Duncan D (1955) Multiple range and multiple F-test. Biometrics 11, 1-42

Hodson TJ (1979) Basidiospore inoculations of soil: the effect of application timing on Pinus ellioti seedling development. S Afr For J 108, 10-15

Marx DH (1969) The influence of ectotrophic mycorrhizal fungi on the resistence of pine roots to pathogenic infections. I. Antagonism of ectomycorrhizal fungi to root pathogenic fungi and soil bacteria. Phytopathology 59, 153-163

Marx DH (1976) Synthesis of ectomycorrhizae on loblolly pine seedlings with basidiospores of Pisolithus tinctorius. For Sci $22,13-20$
Marx DH (1977) Tree host range and world distribution of ectomycorrhizal fungus Pisolithus tinctorius. Can J Bot 23, 217-223

Marx DH, Bell W (1985) Formation of Pisolithus ectomycorrhizae on loblolly pine seedlings with spore pellet inoculum applied at different times. USDA For Res SE-249, 7p

Marx DH, Ross EW (1970) Aseptic synthesis of ectomycorrhizae on Pinus tadea with basidiospores of Thelophora terrestris. Can J Bot 48, 197-198

Marx DH, Mexal JG, Morris WG (1979) Inoculation of nursery seedbeds with Pisolithus tinctorius spores mixed with hydromulch increases ectomycorrhizae and growth of loblolly pines. South J Appl For 3, 175178

Marx DH, Cordell CE, Maul SB, Ruehle JL (1989) Ectomycorrhizal development on pine by Pisolithus tinctorius in bare-root and container seedling nurseries. 11. Efficacy of various vegetative and spore inocula. New For 3, 57-66

Miller SL, Torres P, McLean TM (1993) Basidiospore viability, dormancy, activation and germination in ectomycorrhizal and saprophytic basidiomycetes. Mycol Res 97, 141-149

Molina R (1977) Ectomycorrhizal fungi and forestry practice. In: Mushrooms and Man. An Interdisciplinary Approach to Mycology (Walters T, ed), Forest Service, USDA, 147-161

Ruehle JL (1980) Inoculation of containerized loblolly pine seedlings with basidiospores of Pisolithus tinctorius. USDA For Serv Res Note-291, $4 \mathrm{p}$

Ruehle JL, Marx DH, Abourouh M (1981) Development of Pisolithus tinctorius and Thelephora terrestris ectomycorrhizae on seedlings of coniferous trees important to Morocco. Ann Rech For Maroc 21, 281-296

Theodorou $C$ (1971) Introduction of mycorrhizal fungi into soil by spore inoculation of seed. Aust For 35 , 23-26

Theodorou C (1984) Mycorrhizal inoculation or pine nurseries by sprying basidiospores onto soil prior to sowing. Aust For 47, 76-78

Theodorou C, Bowen GD (1973) Inoculation of seeds and soil with basidiospores of mycorrhizal fungi. Soil Biol Biochem 5, 765-771

Torres $P$, Honrubia M (1994a) Basidiospore viability in stored slurries. Mycol Res 98 (5), 527-530

Torres P, Honrubia M (1994b) Ectomycorrhizal associations proven for Pinus halepensis. Isr J Plant Sci 42, $51-58$

Torres P, Honrubia M, Morte MA (1991) In vitro synthesis of ectomycorrhizae between Suillus collinitus (Fr) O Kuntze, Rhizopogon roseolus (Corda) Th M Fr with Pinus halepensis Miller. Mycotaxon 41, 437-443 